\title{
FBXO5 wt Allele
}

National Cancer Institute

\section{Source}

National Cancer Institute. FBXO5 wt Allele. NCI Thesaurus. Code C116693.

Human FBXO5 wild-type allele is located within $6 q 25-q 26$ and is approximately $13 \mathrm{~kb}$ in length. This allele, which encodes F-box only protein 5 , is involved in both protein ubiquitination and cell cycle progression. 